\title{
ARAH PEMBAHARUAN HUKUM PIDANA INDONESIA DAN KONTRIBUSI HUKUM PIDANA ADAT DI TENGAH PLURALISME HUKUM INDONESIA
}

\author{
I Gede Hady Sunantara ${ }^{1}$ \\ ${ }^{1}$ Kejaksaan Negeri Tabanan-Bali, E-mail: igedehadysunantara@yahoo.com
}

doi: https://doi.org/10.24843/KS.2020.v08.i12.p14

\begin{abstract}
Abstrak
Tujuan penelitian ini untuk mengetahui ara pembaharuan hukum pidana Indonesia di tengah pluralisme hukum Indonesia; dan kontribusi hukum pidana adat dalam pembaharuan hukum pidana di Indonesia. Hasil penelitian ini menunjukkan bahwa Pembaharuan hukum Indonesia saat ini diarahkan kepada upaya re-orientasi substansi aturan-aturan hukum pidana yang dianggap tidak lagi relevan dengan kehidupan masyarakat Indonesia karena banyak perbuatan jahat dalam optik masyarakat tidak termasuk sebagai perbuatan jahat dan dilarang dalam optik hukum positif; dan Kontribusi hukum pidana adat dalam pembaharuan hukum pidana di Indonesia tercermin dari adanya penyelesaian perkara di luar pengadilan atau dikenal dengan istilah mediasi penal, berdasarkan Hukum Pidana Adat mengenai kebiasaan masyarakat Indonesia yang sudah sejak dulu menyelesaikan tindak pidana atau perselisihan di luar pengadilan (mediasi penal) telah membuktikan bahwa kontribusi Hukum Pidana Adat relevan dengan pembaharuan Hukum Pidana di Indonesia.
\end{abstract}

Kata kunci: Hukum Pidana, Pembaharuan, Pluralisme, Pidana Adat

\begin{abstract}
The objective of this research to reveal direction of reforming Indonesian criminal law in the midst of Indonesian legal pluralism; and the contribution of customary criminal law in reforming criminal law in Indonesia. The result of this research indicates that The reform of Indonesian law is currently directed at efforts to re-orient the substance of criminal law rules which are considered no longer relevant to the life of the Indonesian people because many evil acts in society's optics are not considered evil and are prohibited in the optics of positive law; and The contribution of customary criminal law to reforming criminal law in Indonesia is reflected in the settlement of cases outside the court or known as penal mediation. Penal mediation is actually not something new for the Indonesian nation, the provisions regarding penal mediation, based on the Customary Criminal Law regarding the habits of the Indonesian people who have long since resolved criminal acts or disputes outside the court (mediation penal) has proven that the contribution of Customary Criminal Law is relevant to the reform of Criminal Law in Indonesia.
\end{abstract}

Keywords: Criminal Law, Renewal, Pluralism, Customary Crime

\section{Pendahuluan}

\subsection{Latar Belakang Masalah}

Dinamika struktur sosial masyarakat sebagai akibat interaksi yang terjadi secara kontinu membawa konsekuensi perkembangan hukum yang berkembang di masyarakat. Hukum secara kenegaraan berarti hukum dalam arti peraturan 
perundang-undangan, perspektif ini kental dengan nuansa legal positivistic. Hukum yang seperti ini didapat diartikan juga dengan sebutan hukum dalam arti formil. Selain itu juga berkembang aturan hukum yang berkembang dalam masyarakat atau hukum dalam arti materil. Keberadaan hukum formil dan hukum yang hidup dalam masyarakat menandakan terjadinya pluralism hukum di Indonesia. Dewasa ini pembaharuan hukum di Indonesia mulai diarahkan untuk mengakomodasikan hukum yang hidup dalam masyarakat. Pembaharuan hukum pidana Indonesia dirasa perlu untuk memasukkan hukum asli indonesia dalam materi muatan peraturan hukum pidana Indonesia.

Memasukkan hukum asli yang hidup dalam masyarakat, berhubungan dengan suatu perbuatan yang dianggap sebagai tindak pidana. Menurut Rancangan Kitab Undang-Undang Hukum Pidana (RKUHP) syarat perbuatan dianggap sebagai tindak pidana (strafrecht) selain bertentangan dengan peraturan perundang-undangan juga harus bertentangan dengan kesadaran hukum yang hidup dalam masyarakat. ${ }^{1}$ Perlu diketahui bahwa hukum asli Indonesia yang hidup dalam masyarakat berupa hukum adat, hukum agama, dan hukum yang berkembang dalam konfigurasi masyarakat Indonesia. Tak dapat di pungkiri sumber utama dari Hukum Pidana di Indonesia adalah hukum yang tertulis, di samping itu di daerah-daerah tertentu dan untuk orang-orang tertentu seperti halnya masyarakat Bali dengan hukum pidana adat Bali. Hukum Pidana yang tidak tertulis juga digunakan sebagai sumber Hukum Pidana. Sumber Hukum Pidana lainnya adalah Hukum Pidana Adat. ${ }^{2}$

Pembaharuan hukum pidana Indonesia yang diarahkan kepada mengakomodasi hukum yang hidup dalam masyarakat ke dalam materi muatan peraturan hukum pidana merupakan bentuk dari politik kriminal melalui upaya kriminalisasi perbuatan. Upaya yang demikian merupakan usaha menekan kejahatan yang terjadi di masyarakat, sekaligus linier dengan upaya menciptakan kesejahteraan karena kondusifitas dalam kehidupan sosial masyarakat menjadi salah satu penunjang terciptanya kesejahteraan masyarakat. Kemajemukan atau pluralisme hukum merupakan suatu keuntungan namun juga menjadi permasalahan karena pluralisme hukum apabila tidak diakomodir di dalam peraturan perundang-undangan dapat menjadi pemicu tidak efektifnya hukum, karena hukum tersebut tidak sejalan dengan kultural masyarakat atau dapat diartikan masyarakat tidak menginginkan hukum yang tidak sesuai dengan masyarakat. ${ }^{3}$

Mengakomodasi hukum yang hidup di dalam masyarakat pada prinsipnya merupakan langkah yang dinilai bagus mengingat sejarah bangsa Indonesia yang pernah dijajah oleh belanda yang menyebabkan sistem hukum Indonesia (pada waktu dijajah disebut hindia belanda) mengikuti sistem hukum negeri belanda dan lebih miris lagi ketika pasca kemerdekaan hukum yang berlaku khususnya hukum pidana tetap hukum negeri belanda menggunakan asas korkondansi. Pengakomodasian hukum yang hidup di masyarakat memiliki persoalan apakah yang diakomodir adalah nilai-nilai dalam artian perbuatannya saja yang dianggap bertentangan dengan masyarakat atau keseluruhan termasuk kepada tindakan-tindakan adat yang berlaku terhadap perbuatan yang dilanggarnya, karena apabila tidak menyertakan tindakan adat akan menghilangkan esensi dari hukum adat yang bertujuan pemulihan yang

${ }^{1}$ Syamsul Fatoni. Pembaharuan Sistem Pemidanaan: Perspektif Teoritis Dan Pragmatis Untuk Keadilan. Jakarta: Setara Press, (2015). h.32.

2 Sudarto. Hukum Pidana. Semarang: Yayasan Sudarto, (2009). h. 28.

3 I Made Widnyana. Hukum Pidana Adat Dalam Pembaharuan Hukum Pidana. Jakarta: Fikahati Aneska, (2013). h.59. 
merupakan corak ketimuran yang mempunyai falsafah autentik, tidak sama dengan bangsa lain khususnya bangsa barat. ${ }^{4}$

\subsection{Rumusan masalah}

Berdasarkan uraian di atas maka rumusan masalah dalam penelitian ini sebagai berikut: pertama, bagaimana arah pembaharuan hukum pidana Indonesia di tengah pluralisme hukum Indonesia?; dan Kedua, bagaimana kontribusi hukum pidana adat dalam pembaharuan hukum pidana di Indonesia?.

\subsection{Tujuan Penelitian}

Tujuan penelitian ini untuk menganalisis arah pembaharuan hukum pidana Indonesia di tengah pluralisme hukum Indonesia; dan kontribusi hukum pidana adat dalam pembaharuan hukum pidana di Indonesia.

\section{Metode Penelitian}

Metode penelitian yang digunakan dalam penelitian ini adalah jenis penelitian hukum normatif. Penelitian hukum normatif (normative legal research) merupakan penelitian yang dilakukan dengan cara mengkaji peraturan perundang-undangan yang berlaku atau diterapkan terhadap suatu permasalahan hukum tertentu. Penelitian hukum normatif meneliti hukum dari perspektif internal dengan objek penelitiannya adalah norma hukum. ${ }^{5}$ Penelitian normatif seringkali disebut dengan penelitian doktrinal, yaitu penelitian yang objek kajiannya adalah dokumen peraturan perundang-undangan dan bahan pustaka. ${ }^{6}$ Penelitian hukum normatif juga disebut penelitian yang difokuskan untuk mengkaji penerapan kaidah-kaidah atau norma dalam hukum positif.7 Menurut I Made Pasek Diantha penelitian hukum normatif berfungsi untuk memberi argumentasi yuridis ketika terjadi kekosongan, kekaburan dan konflik norma. Lebih jauh ini berarti penelitian hukum normatif berperan untuk mempertahankan aspek kritis dari keilmuan hukumnya sebagai ilmu normatif. ${ }^{8}$

\section{Hasil dan Pembahasan}

\subsection{Arah Pembaharuan Hukum Pidana Indonesia di Tengah Pluralisme Hukum Indonesia}

Struktur sosial berupa hubungan antar individu-individu dalam konfigurasi sosial merupakan basis dari hukum yang mana struktur sosial yang dinamis berdampak kepada perubahan pola kehidupan. ${ }^{9}$ Perubahan struktur sosial yang merupakan basis hukum membawa konsekuensi hukum harus mengikuti perubahan

4 Teguh Prasetyo. Keadilan Bermartabat: Perspektif Teori Hukum. Jakarta: Nusa Media, (2015). h. 27.

5 I Made Pasek Diantha. Metodologi Penelitian Hukum Normatif dalam Justifikasi Teori Hukum. Jakarta: Prenada Media Group, (2017). h.12.

6 Peter Mahmud Marzuki. Penelitian Hukum. Jakarta: Kencana Prenida Media, (2011). h.34.

7 Johny Ibrahim. Teori dan Metodologi Penelitian Hukum Normatif. Malang: Banyumedia, (2012). h.295.

8 I Made Pasek Diantha, op.cit. h.12.

9 R. Suteki. Desaisn Hukum di Ruang Sosial. Bantul: Thafa Media, (2013). h. 36. 
yang terjadi. Perubahan ini menuntut hukum untuk memperbaharui dirinya. Pembaharuan hukum Indonesia khususnya hukum pidana dirasa perlu mengingat sejarah sistem hukum pidana Indonesia menganut sistem hukum barat yang tentu berbeda apabila ditinjau dari perspektif tujuan hukum barat dan timur. Indonesia sebagai negara timur harusnya menggunakan cara berhukum yang memiliki nuansa kultur ketimuran. Achmad Ali mengemukakan bahwa tujuan hukum menurut bangsa timur/asia atau bisa disebut sebagai teori tujuan hukum timur, yang tidak menempatkan mengenai "kepastian", melainkan lebih menekankan kepada prinsip: keadilan adalah keharmonisan, dan keharmonisan adalah kedamaian. ${ }^{10}$ Prinsip keadilan sebagaimana yang dikemukakan oleh Acmad Ali tersebut dipandang selaras pula dengan prinsip keadilan menurut falsafat Pancasila sebagai landasan ideologi bangsa Indonesia yang menuntut adanya keseimbangan dan keselarasan antara kepentingan individu, masyarakat, bangsa, dan negara. ${ }^{11}$ Akan tetapi kenyataannya indonesia menggunakan kultur barat yang penuh nuansa legal formalistik, tentu hal itu menimbulkan pluralism hukum yang negatif.

Menyikapi kondisi hukum Indonesia yang masih berkultur barat akibat berlakunya asas korkondansi negara belanda kepada bangsa jajahannya, diperlukan pembaharuan hukum dalam kaitannya dengan hukum yang asli Indonesia. Menurut Sudarto pembaharuan hukum, khususnya hukum pidana dirasa memiliki tingkat urgensi yang tinggi karena menyangkut tiga hal pertama, alasan politik yaitu suatu negara merdeka harus mempunyai hukum sendiri yang bersifat nasional, demi kebanggaan nasional. Kedua, alasan sosiologis merupakan alasan yang menghendaki hukum mencerminkan kebudayaan dari suatu bangsa. Ketiga, alasan praktis menginginkan hukum yang berlaku di suatu negara merupakan hukum dengan bahasa asli negara tersebut, bukan terjemahan dari hukum itu berasal.12

Pembaharuan hukum pidana merupakan bagian dari pembaharuan hukum secara luas. Menurut Barda Nawawi Arief pembaharuan hukum pidana pada hakikatnya merupakan bagian dari upaya rasional mengefektifkan penegakan hukum melalui memperbaiki legal substance, upaya rasional menanggulangi kejahatan (perbuatan jahat baik oleh undang-undang maupun oleh masyarakat), upaya rasional mengatasi permasalahan-permasalahan sosial yang dapat diselesaikan melalui hukum..$^{13}$ Pembaharuan hukum pidana dapat diartikan sebagai politik hukum dalam arti post factum atau politik hukum dilaksanakan ketika telah terjadi situasi-situasi kongkrit dalam masyarakat. Lebih lanjut Sunaryati Hartono selanjutnya dikutip oleh Barda Nawai Arif mengatakan bahwa politik hukum tidak terlepas dari realita sosial dan tradisional yang terdapat di suatu negara. ${ }^{14}$

Sudarto memberikan pendapat mengenai kebijakan hukum pidana kaitannya dengan kriminalisasi harus diperhatikan hal-hal berikut: (1) Harus memperhatikan tujuan pembangunan nasional yang data mewujudkan masyarakat adil dan makmur berdasarkan Pancasila; dan (2) Perbuatan yang akan dilarang oleh hukum pidana

${ }^{10}$ Achmad Ali. Teori Hukum dan Teori Peradilan. Jakarta: Prenada Media Group, (2009). h. 45 .

${ }^{11}$ J E Sahetapy. Suatu Studi Khusus Mengenai Ancaman Pidana Mati Terhadap Pembunuhan Berencana. Jakarta: Rajawali, (2012). h. 27.

${ }^{12}$ Muladi. Lembaga Pidana Bersyarat, Cetakan Ketiga. Bandung: Alumni, (2015). h.71.

${ }^{13}$ Syamsul Fatoni, op.cit, h. 106.

14 Barda Nawawi Arief. Bunga Rampai Kebijakan Hukum Pidana (Perkembangan Penyusunan Konsep KUНРВаru). Jakarta: Kencana Prenada Media Group, (2012). h.36. 
harus merupakan perbuatan yang tidak dikehendaki oleh masyarakat; ${ }^{15}$ Bertolak dari tujuan nasional dari Sudarto dan Barda Nawawi Arief, Syamsul Fatoni berpendapat pembaharuan hukum pidana harus ditunjukkan kepada: (1) Perlindungan masyarakat dari perbuatan/tindakan asocial yang merugikan dan membahayakan; (2) Perbaikan pelaku perbuatan/tindakan asocial sebagai bentuk perlindungan masyarakat dari sifat berbahaya; dan (3) Penegakan hukum yang menyelesaikan konflik dengan cara memulihkan keseimbangan yang hilang akibat tindak pidana. ${ }^{16}$

Pembaharuan hukum pidana sebagaimana disebutkan diatas berkaitan dengan kriminalisasi yang mana berkaitan dengan perbuatan yang melawan hukum. Suatu perbuatan melawan hukum dalam ranah hukum pidana harusnya sudah final yaitu perbuatan yang bertentangan dengan hukum tertulis sebagai konsekuensi berlakunya prinsip lex certa hal ini dapat diartikan sebagai sifat melawan hukum formil. ${ }^{17}$ Namun dalam doktrin dikenal melawan hukum materil yaitu perbuatan yang bertentangan dengan kepatutan atau nilai-nilai keadilan dalam masyarakat. ${ }^{18}$ Melawan hukum formil dan materil terkadang bertentangan akibat dari tidak komperhensifnya undangundang. Sebagai contoh overspel pasangan muda-mudi yang tidak dalam ikatan perkawinan dianggap bukan perbuatan melawan hukum secara formil, namun secara melawan hukum materil adalah perbuatan yang tidak patut karena masyarakat mengutuknya.

Arah pembaharuan hukum pidana Indonesia berada pada posisi bagaimana mengakomodir hukum yang hidup dalam masyarakat kedalam hukum positif dalam bingkai tujuan nasional yang berkiblat kepada pancasila sekaligus alternatif yang bisa digunakan untuk menyikapi pluralism (kemajemukan) hukum di Indonesia agar dapat menghindari pertentangan antara hukum yang satu dengan hukum yang lainnya. Mengakomodir hukum yang hidup dalam masyarakat merupakan upaya peninjauan kembali sejumlah larangan-larangan yang sifatnya amoral akan tetapi tidak diatur dalam hukum positif. Kebijakan meningkatkan perbuatan amoral sebagai perbuatan pidana menurut Devlin, moralitas merupakan cerminan eksistensi masyarakat. pengendalian tindakan amoral oleh hukum dapat dibenarkan, sehingga kriminalisasi didasarkan kepada perbuatan yang dianggap amoral dapat dibenarkan. ${ }^{19}$ Sejalan dengan pendapat dari Devlin menurut Sudarto pembaharuan hukum pidana Indonesia saat ini diarahkan kepada re-orientasi pokok-pokok pikiran, ide-ide dasar, atau nilai sosio-filosofis, sosio-kultural dan sosio-politik hukum pidana Indonesia sesuai dengan tujuan nasional yang bersemayam dalam ideologi bangsa. ${ }^{20}$

Memperhatikan arah pembaharuan hukum pidana Indonesia yaitu bagaimana menyelaraskan dengan tujuan nasional melalui mengakomodir hukum yang hidup di dalam masyarakat kedalam hukum positif. Pembaharuan hukum pidana, khususnya hukum pidana materil berhubungan langsung dengan kriminalisasi perbuatan. Menurut Soerjono Soekanto, kriminalisasi merupakan tindakan atau penetapan

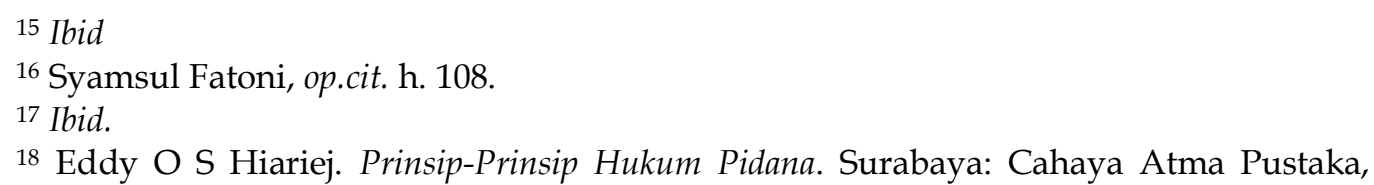
(2016). h. 44

19 Lidya Suryani Widayati. Kebijakan Kriminalisasi Kesusilaan dalam Rancangan Undang-Undang Tentang Hukum Pidana dari Perspektif Moral (Criminalization of Decency In The Criminal Code Bill From Moral Perspectives). Negara Hukum: Membangun Hukum Untuk Keadilan Dan Kesejahteraan, Vol. 9, No. 2, (2019). h. 188.

20 Syamsul Fatoni, op.cit, h.108. 
penguasa mengenai perbuatan-perbuatan tertentu yang oleh masyarakat atau golongan-golongan masyarakat dianggap sebagai perbuatan yang dapat dipidana menjadi perbuatan pidana atau membuat suatu perbuatan menjadi perbuatan kriminal dan karena itu dapat dipidana oleh pemerintah dengan cara kerja atas namanya. ${ }^{21}$

Tindakan kriminalisasi oleh negara merupakan ranah pembentuk undangundang (legislation) yang memiliki batasan bertujuan melindungi masyarakat (warga negara) sebagai subjek yang diaturnya agar tidak terkekang kebebasannya. ${ }^{22}$ Kriminalisasi memiliki hubungan dengan perubahan-perubahan yang terjadi dalam masyarakat. Perubahan sosial tidak hanya berarti perubahan struktur dan fungsi masyarakat, tetapi di dalamnya terkandung juga perubahan nilai, sikap dan pola tingkah laku masyarakat. Apabila diperhatikan kriminalisasi erat kaitannya dengan kondisi struktur sosial, artinya struktur sosial mempengaruhi suatu perbuatan dikategorikan layak sebagai tindak pidana manakala perbuatan tersebut melawan hukum dalam arti materil (mala in perse).

Kriminalisasi perbuatan yang dirasa bertentangan dengan nilai-nilai yang hidup dalam masyarakat tidak dapat dilepaskan dari pendapat Eugent Erlich mengenai living law. Sehingga kriminalisasi perbuatan wajib hukumnya kehendak dalam struktur sosial melalui kaidah-kaidah yang disepakati sebagai pintu utama kriminalisasi. Memperhatikan hal tersebut dalam rangka kriminalisasi adalah elaborasi mempertemukan hukum positif dengan hukum yang hidup dalam masyarakat yang sering bertentangan.

Pandangan living law terhadap hukum memperlihatkan sisi lain hukum yang bukan hanya sekadar hukum dalam arti formal (formal legalistik). Hukum lahir dalam ranah pengalaman sehari-hari, terbentuk lewat kebiasaan yang akhirnya menjadi tatanan yang efektif dalam masyarakat. ${ }^{23}$ Tatanan yang melarang suatu perbuatan biasanya dianggap bertentangan dengan kepatutan dalam kehidupan sosial. Menurut Suteki kaitannya dengan living law menyatakan hukum itu tidak jatuh dari langi melainkan berproses dalam dinamika masyarakat dan menciptakan keajegan-keajegan tertentu. ${ }^{24}$

Kriminalisasi perbuatan yang bertentangan dengan hukum yang hidup dalam masyarakat salah satu patokannya adalah hukum adat. Sifat hukum adat dalam memandang pelanggaran adalah pemulihan, artinya ada tindakan-tindakan adat yang harus dilakukan. Kongkritnya tindakan pemulihan antara lain pembayaran denda adat. $^{25}$ lebih lanjut Hilman Hadikusuma menyebutkan karakteristik hukum pidana adat berupa adanya ketertautan antara yang nata dan tidak nyata, kekuatan manusia dan kekuatan ghaib yang berdampak terganggunya harmoni yang terbangun dalam ketertautan yang dimaksudkan. ${ }^{26}$ Karakteristik tersebut membawa konsekuensi penyelesaian konflik yang terjadi dalam ranah pidana adat berupa pelaksanaan sejumlah ritual guna memulihkan harmoni yang rusak akibat dilakukannya delik adat.

21 Soerjono Soekanto, Hengkie Liklikuwata and Mulyana W Kusumah. Kriminologi: Suatu Pengantar. Jakarta: Ghalia Indonesia, (2001). h.35.

22 Marthen H. Toelle. Kriminalisasi Ditinjau Dari Perspektif Teori Hukum Pidana (Criminal Law Theory). Refleksi Hukum: Jurnal Ilmu Hukum, Vol.8, No. 2, (2014). h.115-32.

23 Bernard L. Tanya, Yoan Nursari Simanjuntak and Markus Y. Hage. Teori Hukum. Jakarta: Genta Publishing, (2013). h.42.

24 Suteki. op.cit. h.43.

25 Sudiyat Imam. Hukum Adat Sketsa Asas. Yogyakarta: Liberty, (2001). h.26.

26 Lilik Mulyadi. Hukum Pidana Adat Kajian Asas, Toeri, Norma Praktik Dan Prosedur. Bandung: PT. Alumni, (2015). h.65. 
Persoalan kriminalisasi saat ini adalah menekankan kepada perbuatan yang dilarang namun tidak diikuti dengan sanksi dengan corak adat yang tujuannya pemulihan yang tercermin melalui ritual-ritual adat. RKUHP sebagai ius contituendum memiliki arah yang futristik dimana jenis sanksi lebih bervariasi dibandingkan Kitab Undang-Undang Hukum Pidana (KUHP) saat ini yang merupakan warisan belanda dengan corak budaya yang berbeda. KUHP saat ini dengan corak baratnya berorientasi kepada keadilan, kepastian dan kemanfaatan. Sedangkan Indonesia sebagai negara timur berorientasi kepada kedamaian sebagai tujuan hukum. ${ }^{27}$ Falsafah (tujuan) bangsa Indonesia merupakan falsafah yang digali dari budaya dan kehidupan bangsa Indonesia yang sudah ada sejak ratusan tahun lalu. Menurut Soediman Kartohadiprojo falsafah bangsa Indonesia bukan individu yang bebas namun individu yang terikat dalam arti kekeluargaan. ${ }^{28}$

Argumentasi didasarkan kepada kenyataan dalam masyarakat adat bahwa pelanggaran (tindak pidana) dipandang sebagai gangguan terhadap keseimbangan (evenwichtstoring), keselarasan, dan keserasian, dalam kehidupan masyarakat yang mengakibatkan kerusakan individual maupun masyarakat. Pemidanaan merupakan reaksi masyarakat yang bertujuan untuk memulihkan kembali rusaknya keseimbangan, keserasian, dan keselarasan sebagai akibat dari suatu pelanggaran (tindak pidana). ${ }^{29}$ Rusaknya keseimbangan, keserasian, dan keselarasan sebagai suatu kekacauan (tidak damai) dibalas dengan melaksanakan ketentuan adat bertujuan mengembalikan rusaknya keseimbangan, keserasian, dan keselarasan agar menjadi damai kembali merupakan tujuan hukum berorientasi ketimuran.

Pembaharuan hukum pidana yang mulai mengarah kepada tujuan hukum yang bercorak ketimuran dipandang telah mengakomodasi nilai-nilai yang hidup dalam masyarakat serta upaya mengelaborasikan sistem hukum yang ada di Indonesia yaitu bagaimana mempertemukan antara hukum modern melalui legal formalistiknya dengan nilai-nilai yang hidup dalam masyarakat sebagai sumber nilainya. Namun alangkah lebih komperhensifnya apabila ketentuan pembayaran adat ditempatkan sebagai pidana pokok bukan sebagai pidana tambahan, sehingga menjadi yang utama (primer) namun kepada tindak pidana yang dikristaliasasi dari ketentuan adat atau tindak pidana adat yang kemudian diatur dalam hukum positif yang secara otomatis diikuti dengan sistem sanksi agar tidak menghilangkan ciri hukum adat sekaligus pengejawantahan corak ketimuran yaitu hadirnya kedamaian. Pengejawantahan ini juga merupakan bentuk social defence yang menurut Marc Ancel masyarakat dalam konfigurasi sosialnya mensyaratkan adanya ketertiban sosial melalui seperangkat aturan yang sesuai kebutuhan dan sesuai aspirasi. ${ }^{30}$

\subsection{Kontribusi Hukum Pidana Adat dalam Pembaharuan Hukum Pidana di Indonesia}

Secara sederhana, pluralisme hukum hadir sebagai kritikan terhadap sentralisme dan positivisme dalam penerapan hukum kepada rakyat. Terdapat beberapa jalan dalam memahami pluralisme hukum. Pertama, pluralisme hukum menjelaskan relasi berbagai sistem hukum yang bekerja dalam masyarakat. Kedua, pluralisme hukum memetakan berbagai hukum yang ada dalam suatu bidang sosial.

27 Achmad Ali, op.cit, h.43.

28 Teguh Prasetyo, op.cit, h.76.

${ }^{29}$ Muladi, op.cit, h.42.

30 Ibid. 
Ketiga, menjelaskan relasi, adaptasi, dan kompetisi antar sistem hukum. Ketiga, pluralisme hukum memperlihatkan pilihan warga memanfaatkan hukum tertentu ketika berkonflik. Dari tiga cara pandang tersebut dan masih banyak cara pandang lainnya, secara ringkas bisa dikatakan bahwa pluralisme hukum adalah kenyataan dalam kehidupan masyarakat. Senada dengan itu, meminjam ungkapan dari Brian Z. Tamanaha, legal pluralism is everywhere. ${ }^{31}$ Ungkapan ini menegaskan bahwasanya di area sosial keragaman sistem normatif adalah keniscayaan. Namun, hal menarik tentang pluralisme hukum bukan hanya terletak pada keanekaragaman sistem normatif tersebut, melainkan pada fakta dan potensi untuk saling bersitegang hingga menciptakan ketidakpastian. Ketidakpastian ini menjadi salah satu titik lemah yang "diserang" dari pluralisme hukum, walaupun hal ini tidak sepenuhnya benar karena permasalahan pokok dari potensi konflik tersebut adalah adanya relasi yang asimetris dari sistem normatif tersebut.

Sejalan dengan itu, John Griffiths mengemukakan konsep pluralisme hukum yang lemah (weak pluralism) dan pluralisme hukum yang kuat (strong pluralism). ${ }^{32}$ Pluralisme hukum disebut sebagai pluralisme hukum yang lemah ketika negara mengakui kehadiran anasir sistem hukum lain di luar hukum negara, tetapi sistemsistem hukum non negara tersebut tunduk keberlakuannya di bawah hukum negara. Sementara itu, pluralisme hukum yang kuat hadir ketika negara mengakui keberadaan hukum non negara dan sistem hukum tersebut mempunyai kapasitas keberlakuan yang sama dengan hukum negara.

Mengenai relevansi hukum pidana adat sebagai kontribusi dalam Pembaharuan Hukum Pidana di Indonesia, pendapat Muladi yang dikutip oleh Lilik Mulyadi, ${ }^{33}$ menambahkan mengenai sistem Hukum Pidana Nasional di masa mendatang/ius constituendum, bahwa idealnya dibentuk suatu Hukum Pidana Materil dengan lima karakteristik sebagai berikut:

Pertama, hukum pidana nasional dibentuk tidak sekadar alasan sosiologis politis dan praktis semata-mata namun secara sadar harus disusun dalam kerangka ideologi nasional Pancasila. Karakteristik ini dapat diartikan, sebagai wajah nasional dari politik kriminal Indonesia. Kedua, hukum pidana nasional di masa mendatang tidak boleh mengabaikan aspek-aspek yang berkaitan dengan kondisi manusia, alam dan tradisi Indonesia. Karakteristik ini dapat diartikan, merupakan wajah politik kriminal Indonesia yang berpijak pada jati diri bangsa dan lingkungan alam Indonesia. Ketiga, hukum pidana mendatang harus bisa menyesuaikan diri dengan kecenderungankecenderungan universal yang tumbuh dalam pergaulan masyarakat beradab. Karakteristik ini dapat diartikan, menghendaki agar politik kriminal Indonesia tidak boleh tertinggal, dan seyogyanya selalu relevan dengan perkembangan tindak pidana internasional dan reaksi masyarakat internasional terhadap tindak pidana tersebut. Keempat, hukum pidana mendatang harus memikirkan aspek-aspek yang bersifat preventif. Karakteristik ini dapat diartikan, mensyaratkan agar politik kriminal Indonesia tidak meninggalkan fungsi pidana sebagai ultimum remidium. Kelima, hukum pidana mendatang harus selalu tanggap terhadap perkembangan ilmu pengetahuan dan teknologi guna meningkatkan efektif fungsinya dalam masyarakat. Karakteristik

${ }^{31}$ B. Z. Tamanaha. Understanding Legal Pluralism: Past To Present, Local To Global. Sydney Law Review, Vol.30, No.2, (2008). h. 405. h.117.

32 J. Griffiths. What is Legal Pluralism?. Journal of Legal Pluralism, Vol.6, No.8, (2006).

${ }^{33}$ Ibid, h.41. 
ini diartikan, mensyaratkan agar proses pembentukan sistem Hukum Pidana nasional seyogyanya sejalan dengan perkembangan ilmu pengetahuan dan teknologi.

Berdasarkan penjelasan tersebut, Lilik Mulyadi, menyimpulkan bahwa kelima karakteristik operasional tersebut pada dasarnya mengandung "tolok ukur, yaitu kepentingan (masyarakat) nasional dan internasional, serta keterkaitan antara kedua kepentingan tersebut satu sama lain dalam menanggulangi akibat pidana, baik tindak pidana di dalam maupun di luar batas teritorial." Relevansi Hukum Pidana Adat sebagai kontribusinya dalam Pembaharuan Hukum Pidana di Indonesia, juga berkaitan dengan Ide Keseimbangan. Dimana implementasi ide keseimbangan dalam tindak pidana didasarkan pada masalah "sumber hukum" (asas legalitas), yakni di samping ketentuan hukum didasarkan pada asas legalitas formil (berdasarkan undang-undang) yang menjadi landasan utama, juga didasarkan pada asas legalitas materiil dengan memberi tempat kepada "hukum yang hidup dalam masyarakat atau hukum tertulis (living law). Begitu juga menurut Barda Nawawi Arief, ${ }^{34}$ mengenai relevansi Hukum Pidana Adat sebagai kontribusi dalam Pembaharuan Hukum Pidana, RKUHP memperluas rumusannya secara "materiel" dengan menegaskan bahwa ketentuan dalam Pasal 1 ayat (1) tidak mengurangi berlakunya "hukum yang hidup" di dalam masyarakat. Dengan demikian, di samping sumber hukum tertulis (undang-undang) sebagai kriteria/patokan formal yang utama. RKUHP juga memberi tempat kepada sumber hukum tidak tertulis yang hidup di dalam masyarakat sebagai dasar menetapkan patut di pidananya suatu perbuatan.

Adapun yang menjadi alasan diperluasnya asas legalitas materiil yang dikutip oleh Rama Putra ada empat. ${ }^{35}$ Pertama, aspirasi yang bersumber dari kebijakan legislatif nasional setelah kemerdekaan (antara lain Pasal 5 ayat (3) sub b, UU No. 1 Drt. 1951). Kedua, aspirasi yang berasal dari interaksi dan kesepakatan ilmiah dalam berbagai seminar atau pertemuan ilmiah lain yang bersifat nasional. Ketiga, aspirasi yang bersifat filosofi dan sosiologis. Keempat, aspirasi universal atau internasional di lingkungan masyarakat bangsa-bangsa yang beradab, melalui "shared values through intellectual and social processes" (enunctiative processes).

Berdasarkan penjelasan pakar-pakar hukum pidana di atas, mengenai perluasan asas legalitas dari perumusan formil (seperti yang berlaku dalam KUHP sekarang ini) ke arah materiil yang dikutip oleh Rama Putra, ${ }^{36}$ didasarkan pada kebijakan legislatif (perundang-undangan) nasional yang keluar setelah kemerdekaan, kesepakatan dalam seminar-seminar nasional, dan kajian perbandingan di negara asing (kajian komparasi). Dari uraian para pakar hukum pidana mengenai perluasan asas legalitas yang awalnya dari asas legalitas formil menuju ke asas legalitas materiil, membuktikan bahwa Hukum Pidana Adat yang hidup dalam masyarakat relevan terhadap pembaharuan Hukum Pidana di Indonesia, dimana hukum yang berlaku dalam masyarakat berlaku dan memiliki tempat sebagai dasar menetapkan patut atau tidaknya suatu perbuatan dikatakan dapat dipidana.

Berbicara mengenai pembaharuan hukum pidana secara umum didasarkan pada nilai socio politic, socio philosophy dan socio culture pada landasan normatif dan substantif hukum pidana di Indonesia. Dalam hal ini hukum pidana adat merupakan kekayaan atau unsur dalam hukum nasional bangsa indonesia, dikatakan demikian bukan berarti seluruh aspek dari hukum pidana adat dapat digunakan sebagai

34 Barda Nawawi Arief, op.cit, h.78.

35 Rama Putra. Ide Keseimbangan Dalam Pembaharuan Sistem Pemidanaan di Indonesia. Semarang: Universitas Diponegoro, (2015). h.145.

36 Ibid, h.146. 
penunjang dalam pembaharuan hukum pidana di Indonesia namun beberapa kajian atau pengaturan dalam hukum pidana adat yang sudah diterapkan secara turun temurun yang sesuai dengan sistem hukum nasional yang dapat dimasukkan dan ditetapkan dalam hukum pidana tertulis sebagai hukum pidana nasional di Indonesia.

Salah satu unsur yang dapat dimasukkan dalam hukum pidana tertulis sebagai aspek pembaharuan hukum pidana yaitu mengenai penyelesaian perselisihan atau tindak pidana secara musyawarah atau mediasi penal. Di mana pada masyarakat adat Bali semua perselisihan atau tindak pidana pada awalnya diselesaikan berdasarkan musyawarah, hal ini sudah dilakukan sejak dahulu dan sudah menjadi tradisi dari masyarakat adat Bali.

M. Syamsudin, juga menjelaskan pendapatnya yang mengenai Hukum Pidana Adat yang memiliki sumbangsih mengenai pembentukan Hukum Nasional di Indonesia. Dalam hal ini perlu dicari asas-asas mana dan kaidah-kaidah atau pranata hukum mana yang sesuai dengan Undang-Undang Dasar Negara Republik Indonesia Tahun 1945 (UUD NRI 1945) dan Pancasila. Sumbangsih Hukum Adat dalam Hukum Nasional antara lain: (a) Asas Kekeluargaan, misalnya merupakan sumbangsih Hukum Adat bagi UUD NRI 1945, karena sudah diangkat dalam Pasal 33 ayat (1) UUD NRI 1945. Dalam bentuk modern, asas kekeluargaan ini perlu dikembangkan lebih lanjut sehingga tidak berhenti pada perwujudan asas kekeluargaan dalam Hukum Adat saja; (b) Sumbangsih Hukum Adat yang paling prinsip dapat berwujud pendekatan terhadap hukum, yang nanti akan menghasilkan sistematika Hukum Nasional, yang lebih cocok dan modern dalam sistematik dalam Hukum Eropa Daratan (continental law), yang kini masih dipakai di Indonesia. ${ }^{37}$

Asas-asas dan pendekatan yang digunakan Hukum Pidana Adat yang dapat disumbangkan kepada Hukum Nasional begitu banyak, walaupun perwujudan dan implementasi dari asas-asas, pranata, atau pendekatan Hukum Adat di dalam Hukum Nasional kita tidak mungkin akan sama dengan wujud dan implementasi asas-asas tersebut dalam Hukum Pidana Adat sendiri. Oleh karena itu, dapat di ketahui bahwa hukum pidana adat tidak hanya selaras dengan pembentukan hukum nasional di Indonesia tetapi hukum pidana adat sudah merupakan bagian dari pembentukan Hukum Nasional sendiri. Jadi dapat dikatakan bahwa hukum pidana adat dan hukum nasional merupakan hukum yang asli dari bangsa Indonesia. Meskipun tidak semua permasalahan dapat diselesaikan dengan hukum pidana adat.

Jadi dapat ditarik suatu pokok pemikiran bahwa adanya musyawarah atau mediasi penal yang ada di Indonesia dalam hukum pidana adat di masyarakat adat Bali, telah membuktikan bahwa unsur-unsur hukum pidana adat sesuai atau relevan jika dimasukkan atau diatur dalam hukum pidana nasional guna melakukan pembaharuan hukum pidana di Indonesia, yang sesuai dengan kondisi masyarakat dan nilai-nilai serta cita-cita Bangsa Indonesia. Dimana pembaharuan hukum pidana harus sesuai dengan kondisi masyarakat dan Bangsa Indonesia selain itu mengenai musyawarah atau mediasi penal juga telah tercantum dalam Pancasila pada ayat ke (4) dan alenia ke 4 UUD NRI 1945. Sehingga hal tersebut telah membuktikan adanya relevansi antara hukum pidana adat dengan hukum pidana dalam pembaharuan hukum pidana di Indonesia tentunya dengan dipengaruhi adanya ide keseimbangan hukum pidana, teori mengenai sifat melawan hukum, pemenuhan kewajiban adat,

37 M. Syamsudin. Hukum Adat dan Modernisasi Hukum. Yogyakarta: Fakultas Hukum Universitas Islam Indonesia, (2009). h. 174-175. 
penyelesaian sengketa di luar pengadilan, serta perluasan teori mengenai asas legalitas.

\section{Kesimpulan}

Pembaharuan hukum Indonesia saat ini diarahkan kepada upaya re-orientasi substansi aturan-aturan hukum pidana yang dianggap tidak lagi relevan dengan kehidupan masyarakat Indonesia karena banyak perbuatan jahat dalam optik masyarakat tidak termasuk sebagai perbuatan jahat dan dilarang dalam optik hukum positif. Semua terjadi karena hukum pidana Indonesia secara umum merupakan warisan dari belanda yang secara kultur masyarakat berbeda dengan kultur masyarakat Indonesia yang bercorak ketimuran. Apabila menempatkan hukum sebagai cerminan masyarakat, dengan demikian hukum pidana Indonesia saat ini tidak mencerminkan hal itu, maka pembaharuan hukum pidana Indonesia saat ini mengarah kepada re-orientasi substansi hukum pidana Indonesia sesuai dengan kehendak masyarakat.

Kontribusi hukum pidana adat dalam pembaharuan hukum pidana di Indonesia tercermin dari adanya penyelesaian perkara di luar pengadilan atau dikenal dengan istilah mediasi penal. Mediasi penal sebenarnya bukan merupakan sesuatu yang baru bagi Bangsa Indonesia, ketentuan mengenai mediasi penal secara tidak langsung sudah tersirat dalam Sila ke empat Pancasila yang berbunyi "Kerakyatan yang dipimpin oleh hikmat kebijaksanaan dalam permusyawaratan perwakilan", selain itu juga terdapat dalam alenia ke 4 Pembukaan UUD NRI 1945. Jadi berdasarkan Hukum Pidana Adat mengenai kebiasaan masyarakat Indonesia yang sudah sejak dulu menyelesaikan tindak pidana atau perselisihan di luar pengadilan (mediasi penal) telah membuktikan bahwa kontribusi Hukum Pidana Adat relevan dengan pembaharuan Hukum Pidana di Indonesia.

\section{Daftar Pustaka}

\section{$\underline{\text { Buku }}$}

Ali, Achmad. Teori Hukum dan Teori Peradilan. Jakarta: Prenada Media Group. (2009).

Arief, Barda Nawawi. Bunga Rampai Kebijakan Hukum Pidana (Perkembangan Penyusunan Konsep KUHPBaru). Jakarta: Kencana Prenada Media Group. (2012).

Diantha, I Made Pasek. Metodologi Penelitian Hukum Normatif dalam Justifikasi Teori Hukum. Jakarta: Prenada Media Group. (2017).

Fatoni, Syamsul. Pembaharuan Sistem Pemidanaan: Perspektif Teoritis Dan Pragmatis Untuk Keadilan. Jakarta: Setara Press. (2015).

Hiariej, Eddy O S. Prinsip-Prinsip Hukum Pidana. Surabaya: Cahaya Atma Pustaka. (2016).

Ibrahim, Johny. Teori dan Metodologi Penelitian Hukum Normatif. Malang: Banyumedia. (2012).

Imam, Sudiyat. Hukum Adat Sketsa Asas. Yogyakarta: Liberty. (2001).

Marzuki, Peter Mahmud. Penelitian Hukum. Jakarta: Kencana Prenida Media. (2011).

Muladi. Lembaga Pidana Bersyarat, Cetakan Ketiga. Bandung: Alumni. (2015).

Mulyadi, Lilik. Hukum Pidana Adat Kajian Asas, Toeri, Norma Praktik Dan Prosedur. Bandung: PT. Alumni. (2015).

Prasetyo, Teguh. Keadilan Bermartabat: Perspektif Teori Hukum. Jakarta: Nusa Media. (2015). 
Putra, Rama. Ide Keseimbangan Dalam Pembaharuan Sistem Pemidanaan di Indonesia. Semarang: Universitas Diponegoro. (2015).

Sahetapy, J E. Suatu Studi Khusus Mengenai Ancaman Pidana Mati Terhadap Pembunuhan Berencana. Jakarta: Rajawali. (2012).

Soekanto, Soerjono, Hengkie Liklikuwata and Mulyana W. Kusumah. Kriminologi: Suatu Pengantar. Jakarta: Ghalia Indonesia. (2001).

Sudarto. Hukum Pidana. Semarang: Yayasan Sudarto. (2009).

Suteki, R. Desaisn Hukum di Ruang Sosial. Bantul: Thafa Media. (2013).

Syamsudin, M. Hukum Adat dan Modernisasi Hukum. Yogyakarta: Fakultas Hukum Universitas Islam Indonesia. (2009).

Tanya, Bernard L., Yoan Nursari Simanjuntak and Markus Y. Hage. Teori Hukum. Jakarta: Genta Publishing. (2013).

Widnyana, I Made. Hukum Pidana Adat Dalam Pembaharuan Hukum Pidana. Jakarta: Fikahati Aneska. (2013).

\section{Jurnal}

Griffiths, J. What is Legal Pluralism?. Journal of Legal Pluralism, Vol.6, No.8. (2006).

Tamanaha, B. Z.. Understanding Legal Pluralism: Past To Present, Local To Global. Sydney Law Review, Vol.30, No.2. (2008).

Toelle, Marthen H. Kriminalisasi Ditinjau Dari Perspektif Teori Hukum Pidana (Criminal Law Theory). Refleksi Hukum: Jurnal Ilmu Hukum, Vol.8, No. 2. (2014).

Widayati, Lidya Suryani. Kebijakan Kriminalisasi Kesusilaan dalam Rancangan Undang-Undang Tentang Hukum Pidana dari Perspektif Moral (Criminalization of Decency In The Criminal Code Bill From Moral Perspectives). Negara Hukum: Membangun Hukum Untuk Keadilan Dan Kesejahteraan, Vol. 9, No. 2. (2019).

\section{Peraturan Perundang-Undangan}

Undang-Undang Dasar Negara Republik Indonesia Tahun 1945.

Kitab Undang-Undang Hukum Pidana.

Rancangan Kitab Undang-Undang Hukum Pidana. 